\title{
BEACH CHANGES AROUND DAWU FISHING PORT IN TAIWAN CAUSED BY OBSTRUCTION OF LONGSHORE SAND TRANSPORT AND MEASURES
}

\author{
Takayuki Kumada ${ }^{1}$, Takaaki Uda ${ }^{1}$ and Jimmy J. Y. Liu ${ }^{2}$
}

\begin{abstract}
The Dawu fishing port breakwater has been extending since 1956 in Taitung City located in the southeast part of Taiwan, obstructing southward longshore sand transport. Because of the blockage of longshore sand transport at this fishing port, severe downcoast erosion occurred, resulting in the wave overtopping damage to Route No. 9 extending along the coastline, and urgent measures were required to enhance the safety of the route. As measures, beach nourishment using coarse materials including gravel produced from the construction of a road tunnel was planned, as well as the construction of groins on the downcoast. We first analyzed beach changes around this fishing port using past aerial photographs and bathymetric survey data, and beach changes were reproduced using the contour-line-change model considering changes in grain size. Then, the effect of measures was investigated using the model.
\end{abstract}

Keywords: beach erosion; Taiwan; Dawu fishing port; longshore sand transport; obstruction, contour-line-change model

\section{INTRODUCTION}

Along the east coast of Taiwan, southward longshore sand transport is predominant. The Dawu fishing port breakwater has been extending since 1956 in Taitung City located in the southeast part of Taiwan, obstructing this longshore sand transport. This resulted in sand deposition north of the fishing port and erosion south of it, as well as sand deposition into the navigation channel (So, 1970). So (1970) evaluated the southward longshore sand transport to be $(1.0-1.2) \times 10^{5} \mathrm{~m}^{3} / \mathrm{yr}$ from the change in sand volume accumulated in the area north of fishing port on the basis of the bathymetric survey data between three periods: 1956-1967, 1967-1968, and 1968-1969. Because of the blockage of continuous longshore sand transport at the Dawu fishing port, downcoast erosion is severe. The wave overtopping damage to Route No. 9 extending along the coastline during the typhoon season is severe on the downcoast, and urgent measures are required to enhance the safety of the route. As measures, beach nourishment using coarse materials including gravel produced from the construction of a road tunnel was planned, as well as the construction of groins on the downcoast. In this case, the prediction of the movement of materials with mixed grain sizes is needed. In this study, therefore, we first analyzed beach changes around this fishing port using past aerial photographs and bathymetric survey data, and beach changes were reproduced using the contour-line-change model considering changes in grain size (Uda and Serizawa, 2010). Then, the effect of measures was investigated using the model.

\section{AERIAL PHOTOGRAPH AND BATHYMETRIC CHANGES}

Figure 1 shows the aerial photograph taken in December 2000 of the coast with a $9 \mathrm{~km}$ stretch between the Dawu and Anshuo Rivers including the Dawu fishing port. The Dawu River flows into the Pacific Ocean $2.5 \mathrm{~km}$ north of this fishing port, while forming a fluvial fan with a shoreline projection. In contrast, the shoreline extends in a straight line near the Anshuo River $5 \mathrm{~km}$ south of the fishing port. Up to 2000, the shoreline advanced north of the fishing port, whereas a hooked shoreline was formed south of the fishing port, leaving a narrow entrance channel to the fishing port. This implies that part of the longshore sand transport turned around the tip of the breakwater and sand was transported into the navigation channel. In addition, this demonstrates that sand supplied from the Dawu River and the rivers north of the river has been continuously transported southward.

Figure 2 shows aerial photographs taken in 2000 and 2005 of the rectangular area in Fig. 1. As a measure against sand deposition inside the fishing port, a 250-m-long jetty was extended at the north corner of the existing breakwater until 2005. The shoreline rapidly advanced because of the blockage of longshore sand transport by this jetty. At a point P $300 \mathrm{~m}$ north of the jetty, where the wavesheltering effect of the jetty is negligible, the direction normal to the shoreline is $\mathrm{N} 91^{\circ} \mathrm{E}$, which approximately gives the predominant wave direction near the fishing port. Thus, the construction of the jetty caused the shoreline to advance north of the fishing port and shoreline recession on the downcoast.

\footnotetext{
${ }_{1}^{1}$ Public Works Research Center, 1-6-4 Taito, Taito, Tokyo 110-0016, Japan

${ }^{2}$ Kaohsiung Office, Capital Engineering Corporation, Ltd., 6F-1, No. 12, Fuxing Rd., Kaohsiung 806, Taiwan
} 
Figure 3 shows the bathymetry around the fishing port in 2008. Between the shoreline and $-9 \mathrm{~m}$, a steep slope extends, then the offshore slope gradually decreases, with a gentle slope in the zone deeper than $-9 \mathrm{~m}$, implying that the depth of closure is approximately $9 \mathrm{~m}$ on this coast.

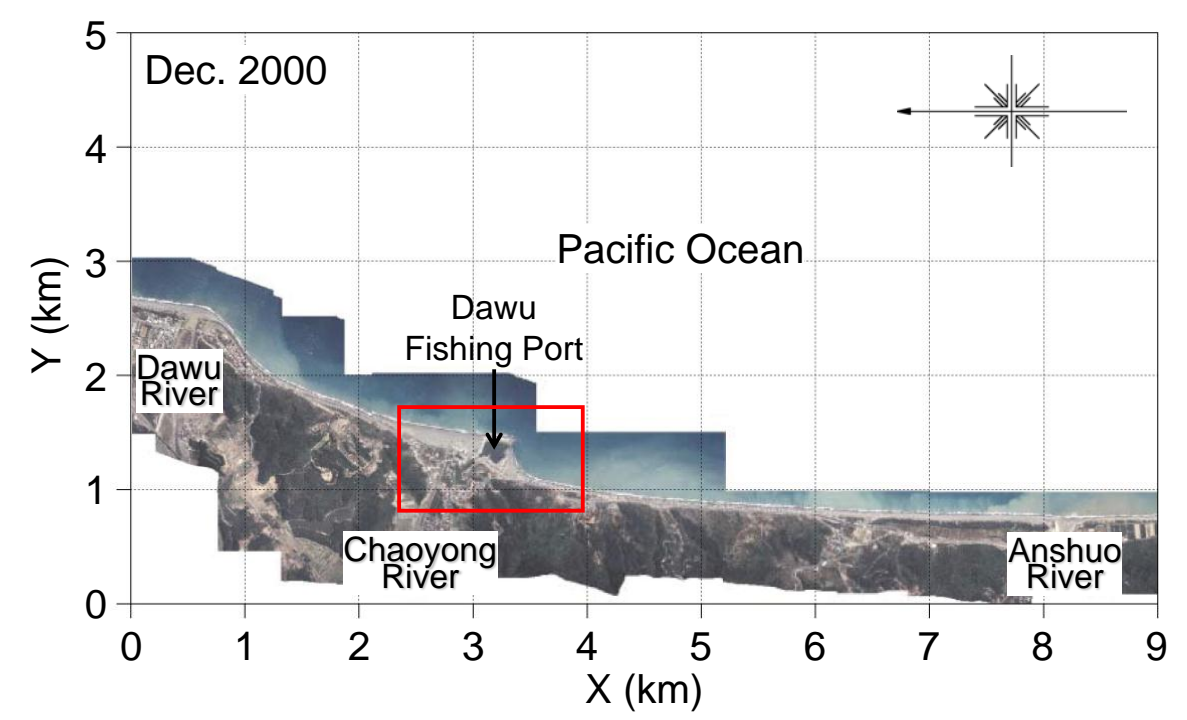

Figure 1. Aerial photograph taken in December 2000 of coast with a 9 km stretch including Dawu fishing port between Dawu and Anshuo Rivers.

(a) 2000

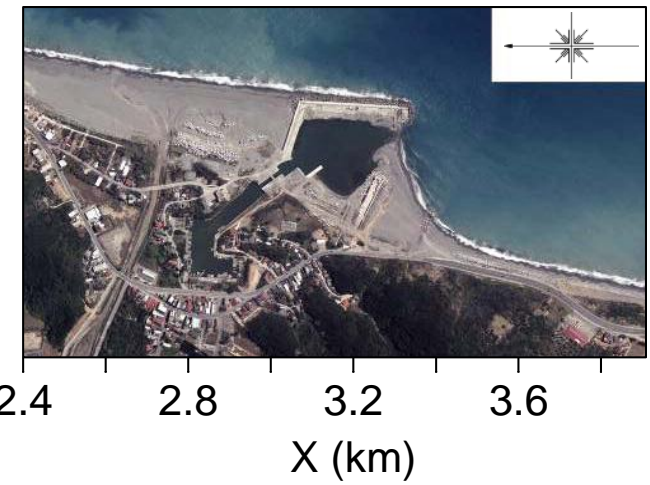

(b) 2005

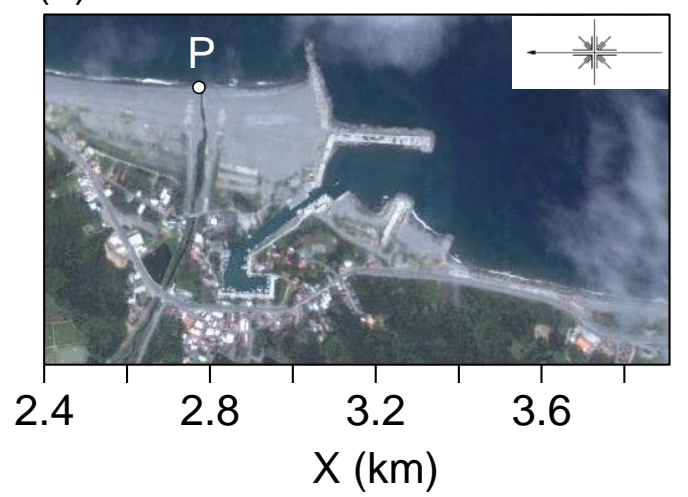

Figure 2. Aerial photographs taken in 2000 and 2005 of rectangular area around Dawu fishing port shown in Fig. 1.

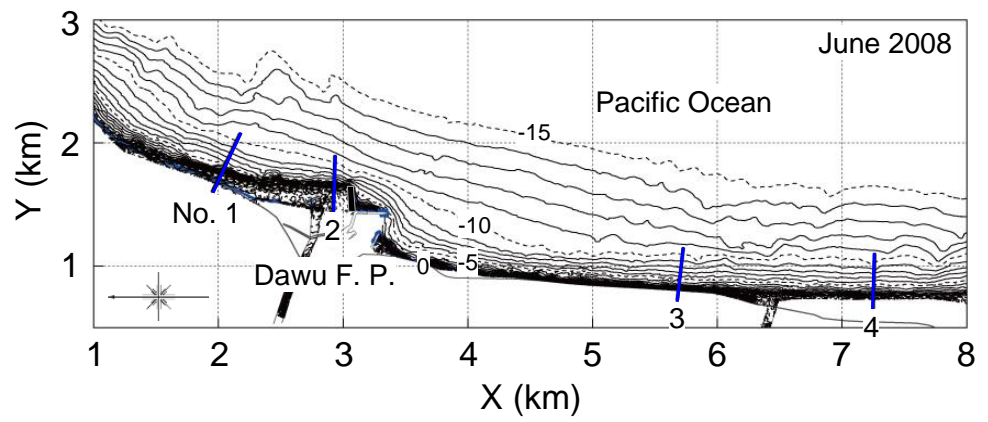

Figure 3. Bathymetry around Dawu fishing port measured in June 2008. 


\section{NUMERICAL MODEL}

The cross-shore transport of sand of mixed grain sizes can be modeled by expanding the concept of a single grain size as described in Uda and Serizawa (2010). The sorting of grain size populations, such as those of fine sand, medium and coarse sand, and gravel, can be modeled by introducing the equilibrium slope angle $\beta_{c}{ }^{(k)}$, which corresponds to each grain size population $k$. In this case, a grain size population is assumed to have a single equilibrium beach slope with a characteristic grain size $d^{(k)}$, for example, the median diameter of the grain size population. By assuming that the mobility of sand of each grain size population by cross-shore movement is the same as that of longshore sand transport, the coefficient of the sediment transport rate for the grain size $d^{(k)}$, which was given by Kamphius et al. (1986) and Kumada et al. (2003), is introduced.

Furthermore, assuming that the ratio of the exposed area of each grain size population to the entire sea bottom area is equal to the content of each size population in the exchange layer $\mu^{(k)}$ (where $k=1,2, \ldots, \mathrm{N})$, the cross-shore sand transport rate of each grain size population $q_{z}^{(k)}$ is derived by a method similar to that of Uda et al. (2004).

Cross-shore sand transport

$$
\begin{gathered}
q_{z}^{(k)}=\mu^{(k)} \cdot \varepsilon_{z}(z) \cdot \gamma \cdot K_{1}^{(k)} \cdot \\
\left(E C_{g}\right)_{b} \cos ^{2} \alpha_{b s} \sin \bar{\beta} \cdot\left(\cot \beta / \cot \beta_{c}^{(k)}-1\right) \\
; k=1,2, \ldots, N \\
K_{1}^{(k)}=\frac{A}{\sqrt{d^{(k)}}} \\
\cot \beta=-\partial Y / \partial z \\
\varepsilon_{z}(z)=\left\{\begin{array}{l}
\left(2 / h_{C}^{3}\right)\left(h_{C} / 2-z\right)\left(z+h_{C}\right)^{2}, \quad-h_{C} \leq z \leq h_{R} \\
0,
\end{array} \quad \begin{array}{r}
2 \leq h_{C}, z \geq h_{R}
\end{array}\right.
\end{gathered}
$$

Here, $q_{z}^{(k)}(k=1, \cdots, N)$ is the cross-shore sand transport per unit length in the longshore direction for each grain size population, $\mu^{(k)}$ is the content of each grain size population $(k)$ in the exchange layer of sand, $\varepsilon_{z}(z)$ is the depth distribution of the sand transport given by Uda and Kawano (1996), and $d^{(k)}$ is a typical grain size of the grain size population. $A$ is a coefficient that depends on the physical conditions of the beach, $d^{(k)}$ in Eq. (2) has a unit of mm, $\gamma$ is the ratio of the coefficient of cross-shore sand transport to the coefficient of longshore sand transport, and expresses the mobility of cross-shore sand transport relative to that of longshore sand transport, $\alpha_{b s}$ is the angle between the wave crest line at the breaking point and each contour line, and $\beta$ is the beach slope angle at each contour line. $\bar{\beta}$ is the average beach slope angle between the berm height $h_{R}$ and the depth of closure $h_{c}$, and $\beta_{C}{ }^{(k)}$ is the equilibrium beach slope angle. When the beach slope becomes steeper than the angle of repose of sand, sand is transported offshore by gravity.

\section{$\underline{\text { Longshore sand transport }}$}

$$
\begin{aligned}
& q_{x}^{(k)}=\mu^{(k)} \cdot \varepsilon_{x}(z) \cdot K_{1}^{(k)} \cdot\left(E C_{g}\right)_{b} \cdot \\
& \left(\cos \alpha_{b s} \sin \alpha_{b s}-\xi \frac{1}{\tan \beta} \cdot \cos \alpha_{b s} \cdot \frac{\partial H_{b}}{\partial x}\right)
\end{aligned}
$$

Here, $q_{x}^{(k)}(k=1, \cdots, N)$ is the longshore sand transport per unit depth for each grain size population, $\varepsilon_{x}(z)$ is the depth distribution of longshore sand transport, and $\xi$ is the constant given by $K_{2}{ }^{(k)} / K_{I}{ }^{(k)}$, which depends on the physical conditions of the beach, where $K_{2}^{(k)}$ is a function of $K_{I}{ }^{(k)}$ and 
is equivalent to the coefficient of Ozasa and Brampton (1980). $\tan \beta$ is the beach slope in the surf zone and $H_{b}$ is the breaker height.

$\underline{\text { Mass conservation for each grain size }}$

$$
\begin{aligned}
& \frac{\partial y^{(k)}}{\partial t}=-\frac{\partial q_{x}^{(k)}}{\partial x}-\frac{\partial q_{z}^{(k)}}{\partial z} \\
& ; k=1,2, \ldots, N
\end{aligned}
$$

The total contour line change at a certain position is determined by the summation of the contour line changes of all grain size populations at that position.

$$
\frac{\partial Y}{\partial t}=\sum_{k=1}^{N} \frac{\partial y^{(k)}}{\partial t}
$$

Change in content of each grain size population

$$
\begin{aligned}
\frac{\partial \mu^{(k)}}{\partial t} & =\frac{1}{B}\left\{\frac{\partial y^{(k)}}{\partial t}-\frac{\partial Y}{\partial t} \cdot \mu^{(k)}\right\} \\
; k & =1,2, \ldots, N .
\end{aligned}
$$

The content of each grain size population in the new exchange layer formed during erosion is expressed as

$$
\frac{\partial \mu^{(k)}}{\partial t}=\frac{1}{B}\left\{\frac{\partial y^{(k)}}{\partial t}-\frac{\partial Y}{\partial t} \cdot \mu_{B}^{(k)}\right\}
$$

where $\mu_{B}^{(k)}$ is the content of each grain size population on the sandy beach landward of the initial exchange layer. The width $B$ of the exchange layer is determined with reference to the mixing depth reported by Kraus (1985). The above-mentioned equations were solved simultaneously.

\section{CALCULATION CONDITIONS}

The wave field was calculated using the bathymetry in 2008, as shown in Fig. 3. For the numerical calculation of the wave field, the energy balance equation given by Mase (2001) with the dissipation term due to wave breaking given by Dally et al. (1984) was used. For the wave data, the results of the wave observation in 2009 at a depth of $30 \mathrm{~m}$ offshore in the north of Taiwan were used: mean wave height of $1.28 \mathrm{~m}$ and period of $7.9 \mathrm{~s}$. The wave direction was estimated from the stable shoreline north of the jetty of the fishing port shown in Fig. 2, because no observation has been made regarding wave direction near the Dawu fishing port. Assuming that the shoreline at point $\mathrm{P}(X=2.8$ $\mathrm{km}) 300 \mathrm{~m}$ north of the jetty is approximately perpendicular to the predominant wave direction, the direction normal to the shoreline is $\mathrm{N} 91^{\circ} \mathrm{E}$.

Given the predominant wave direction of $\mathrm{N} 91^{\circ} \mathrm{E}$ near the fishing port, the calculation was made on the basis of Snell's theory, and the offshore wave direction was reversely evaluated to be $\mathrm{N} 82^{\circ} \mathrm{E}$. The calculation domain of beach changes is the coast of $7 \mathrm{~km}$ length including the Dawu fishing port, as shown in Fig. 4. The open boundary condition where the shoreline position is fixed was adopted as the upcoast boundary condition. The calculation domain was expanded additionally $3 \mathrm{~km}$ on both ends so that the boundary conditions do not affect the calculation domain. The beach changes were assumed to occur between the berm height of $3.5 \mathrm{~m}$ and the depth of closure of $9 \mathrm{~m}$.

The numerical simulation of six cases was carried out: two cases in the reproduction calculation and four cases in the prediction calculation. In reproduction No. 1, the beach changes up to 1998 were reproduced, given the shoreline in 1998 with parallel contours as the model bathymetry for the initial 
condition, as shown in Fig. 4. The bathymetry in 1998, which was assumed to be under a dynamically equilibrium condition, was reproduced, given the breaker height and breaker angle calculated using the energy balance equation. In this case, the initial longitudinal slope was adopted as shown in Table 1 , assuming the mean beach slope that was obtained by superimposing the longitudinal profiles in 2008. The grain size of the seabed materials was assumed to be $0.6 \mathrm{~mm}$ on the basis of the measured values. In reproduction No. 2, the beach changes until 2008 were reproduced, given the reproduced bathymetry in 1998 during which the jetty was constructed north of the fishing port.

In Case 1 of the prediction calculation, the beach changes until 2028 were predicted given the bathymetry in 2008 as the initial bathymetry. In Case 2, groins with a point depth of $5 \mathrm{~m}$ were installed at $200 \mathrm{~m}$ intervals along the area where the minimum beach width of $10 \mathrm{~m}$ was unsatisfied and beach nourishment using coarse materials was carried out. The grain size of nourishment materials was assumed to be $60 \mathrm{~mm}$ with an equilibrium slope of $1 / 3 ; 5 \times 10^{4} \mathrm{~m}^{3}$ of sand was used for beach nourishment to obtain a beach width of $10 \mathrm{~m}$. In Case $3,2.0 \times 10^{5} \mathrm{~m}^{3}$ of gravel was used for beach nourishment to obtain a beach width of $30 \mathrm{~m}$, and groins were also constructed. In Case 4 , sand mining at a rate of $2.0 \times 10^{4} \mathrm{~m}^{3} / \mathrm{yr}$ was further assumed at the entrance channel of the Dawu fishing port.

The contour lines have a large longshore inclination along the downcoast shoreline of the entrance channel of the Dawu fishing port, as shown in Fig. 5(a), such that the breaker angle is larger than $45^{\circ}$ to the direction normal to the shoreline. Because the longshore sand transport equation of the contour-line-change model is of CERC type, shoreline instability will occur when the breaker angle exceeds $45^{\circ}$ (Ashton et al., 2001). In this study, therefore, a breaker angle of greater than $45^{\circ}$ was replaced by $45^{\circ}$.

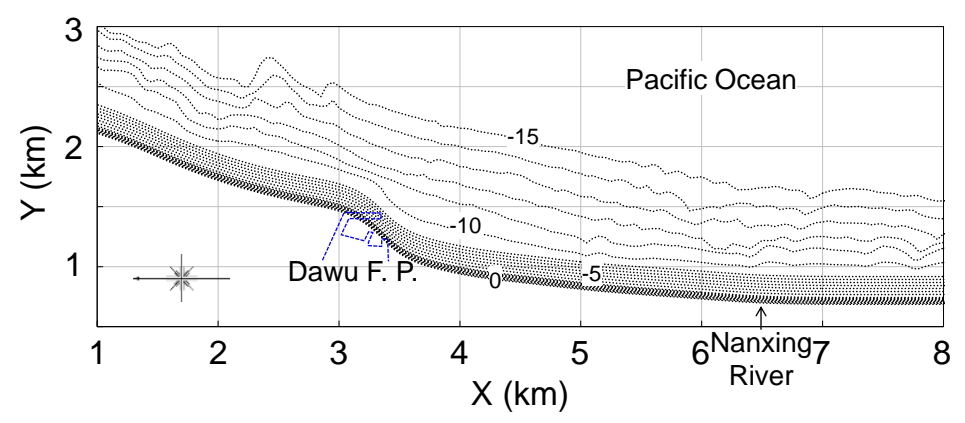

Figure 4. Calculation domain of beach changes.

(a) $\theta_{b}>45^{\circ}$

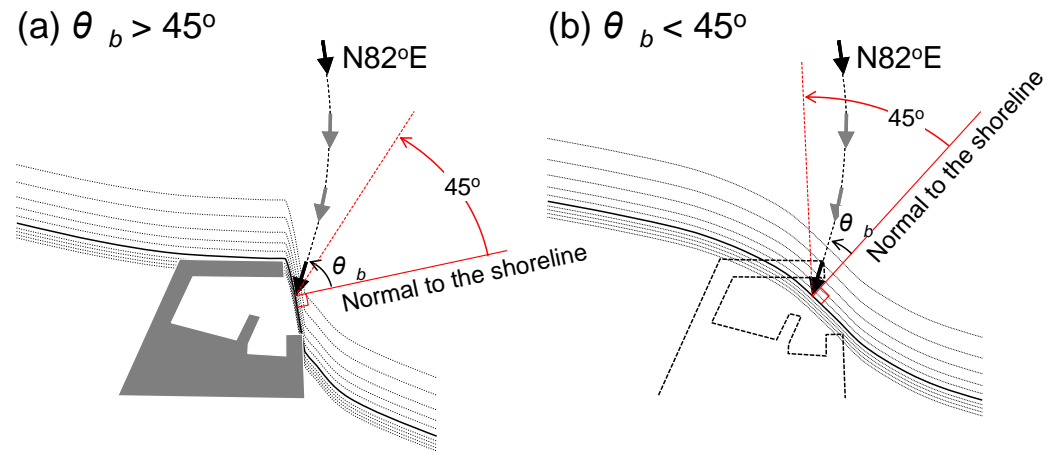

Figure 5. Wave incidence to direction normal to shoreline. 


\begin{tabular}{|c|c|}
\hline $\begin{array}{l}\text { Numerical model of } \\
\text { beach changes }\end{array}$ & Contour-line-change model considering grain size changes (Uda and Serizawa, 2010) \\
\hline Calculation domain & Coast with $9 \mathrm{~km}$ length extending south of Dawu River \\
\hline Cases & $\begin{array}{l}\text { Reproduction calculation } \\
\text { No. 1: bathymetry in } 1998 \\
\text { No. 2: bathymetry in } 2008 \\
\text { Prediction } \\
\text { Case 1: No further measures taken. } \\
\text { Case 2: Beach nourishment of } 5 \times 10^{4} \mathrm{~m}^{3} \text { using coarse materials along with construction } \\
\text { of groins (point depth of } 5 \mathrm{~m} \text { and } 200 \mathrm{~m} \text { intervals) } \\
\text { Case 3: construction of groins (point depth of } 5 \mathrm{~m} \text { and } 200 \mathrm{~m} \text { intervals) }+ \text { gravel } \\
\text { nourishment of } 2.0 \times 10^{5} \mathrm{~m}^{3} \\
\text { Case } 4 \text { : Case } 3+\text { sand mining at the entrance channel at a rate of } 2 \times 10^{4} \mathrm{~m}^{3} / \mathrm{yr}\end{array}$ \\
\hline Initial bathymetry & $\begin{array}{l}\text { Reproduction calculation No. 1: beach slope of } 1 / 8 \text { between } Z=+5 \text { and }-2 \mathrm{~m}, 1 / 25 \\
\text { between } Z=-2 \mathrm{~m} \text { and }-9 \mathrm{~m} \text { and } 1 / 125 \text { deeper than }-9 \mathrm{~m} \\
\text { Reproduction calculation No. 2: Reproduced bathymetry in } 1998 \\
\text { Case 2: Reproduced bathymetry in } 2008+\text { gravel nourishment of } 5 \times 10^{4} \mathrm{~m}^{3} \\
\text { Cases } 3 \text { and 4: Reproduced bathymetry in } 2008+\text { gravel nourishment of } 2.0 \times 10^{5} \mathrm{~m}^{3}\end{array}$ \\
\hline Grain size & $0.6 \mathrm{~mm}$ (bed material) and $60 \mathrm{~mm}$ (nourishment gravel) \\
\hline Equilibrium slope & $\begin{array}{l}1 / 8 \text { shallower than }-2 m \text { and } 1 / 25 \text { between }-2 m \text { and }-9 m ; 1 / 3 \text { (nourishment gravel of } 60 \\
m m \text { diameter) }\end{array}$ \\
\hline Incident wave conditions & $\begin{array}{l}\text { Breaker height } H_{b} \text { : smoothing result of calculated wave height } \\
\text { Wave direction at breaking points } \alpha_{b} \text { : smoothing result of calculated wave direction }\end{array}$ \\
\hline Tide condition & M.S.L. $0.0 \mathrm{~m}$ \\
\hline $\begin{array}{l}\text { Berm height and depth of } \\
\text { closure }\end{array}$ & $\begin{array}{l}\text { Berm height } h_{R}=3.5 \mathrm{~m} \\
\text { Depth of closure } h_{C}=9 \mathrm{~m}\end{array}$ \\
\hline Boundary conditions & $\begin{array}{l}\text { - Open boundary at both ends (fixed shoreline position) } \\
\text { - Installation of seawall with the slope of } 1 / 315 \mathrm{~m} \text { landward of the shoreline } \\
\text { - } \quad \text { Reproduction No. } 2: \text { A groin with point depth of } 7 \mathrm{~m} \text { is installed at } X=3 \mathrm{~km} \\
\text { Cases 2, } 3 \text { and } 4: \text { Installation of seven groins with point depth of } 5 \mathrm{~m} \text { between } X= \\
\text { - } 3.5 \text { and } 4.8 \mathrm{~km} \text { at } 200 \mathrm{~m} \text { intervals } \\
\text { Case } 4 \text { : sand mining of } 2 \times 10^{4} \mathrm{~m}^{3} / \mathrm{yr} \text { in the depth zone between } Z=-3 \mathrm{~m} \text { and }-9 \mathrm{~m} \\
\text { in an area between } X=3.2 \text { and } 3.25 \mathrm{~km}\end{array}$ \\
\hline $\begin{array}{l}\text { Sand transport } \\
\text { coefficients }\end{array}$ & $\begin{array}{l}\text { Coefficient of sand transport } A=0.3 \\
\text { Ozasa and Brampton(1980)'s coefficient } \zeta=0 \\
\text { Ratio of coefficient of cross-shore sand transport relative to that of longshore sand } \\
\text { transport } K_{z} / K_{X}=0.2\end{array}$ \\
\hline $\begin{array}{l}\text { Depth distribution of sand } \\
\text { transport }\end{array}$ & Cubic equation given by Uda and Kawano (1996) \\
\hline $\begin{array}{l}\text { Critical slope of falling } \\
\text { sand }\end{array}$ & $1 / 2$ on land and $1 / 3$ on seabed \\
\hline $\begin{array}{l}\text { Depth range of } \\
\text { calculation }\end{array}$ & Between $Z=5 \mathrm{~m}$ and $-15 \mathrm{~m}$ \\
\hline Mesh sizes & $\Delta X=50 \mathrm{~m}$ and $\Delta Z=1 \mathrm{~m}$ \\
\hline Time intervals & $\Delta t=1 \mathrm{hr}$ \\
\hline $\begin{array}{l}\text { Correspondence of real } \\
\text { time and time steps }\end{array}$ & One year: 8,760 steps \\
\hline
\end{tabular}

\section{RESULTS OF REPRODUCTION CALCULATION}

Figure 6 shows the reproduced bathymetry in 1998. In the reproduction calculation of bathymetric changes until 1998, the calculated and measured shorelines were in good agreement except in the immediate vicinity of the fishing port, and a beach under dynamically equilibrium condition with a constant longshore sand transport of $1.0 \times 10^{5} \mathrm{~m}^{3} / \mathrm{yr}$ was established. Then, the calculation until 2008 was carried out. Figures 7(a) and 7(b) respectively show the measured and calculated bathymetries in 2008. Because a jetty was extended at the Dawu fishing port between 1998 and 2008, sand was deposited upcoast of this jetty and erosion occurred downcoast. The measured and predicted beach changes are also in good agreement.

Figure 8 shows the measured and calculated shoreline changes between 1998 and 2008 with reference to that in 1998. They are also in good agreement in terms of the maximum shoreline advance of $140 \mathrm{~m}$ in the vicinity of the jetty in the calculation compared with $150 \mathrm{~m}$ in the 
measurement, as well as the exposure of the seawall with the disappearance of the foreshore downcoast.

Figure 9 shows the distribution of longshore sand transport. Although longshore sand transport of $1.0 \times 10^{5} \mathrm{~m}^{3} / \mathrm{yr}$ was maintained at all locations in 1998 when the beach was under a dynamically equilibrium condition, it decreased to $2.0 \times 10^{4} \mathrm{~m}^{3} / \mathrm{yr}$ at the jetty after its extension in 2001 with a further decrease in sand transport downcoast. Longshore sand transport, however, increased again at the jetty and downcoast after 2004, implying that longshore sand transport was fully obstructed by the jetty until 2004, but part of the sand had gradually turned around the tip of the jetty owing to the accumulation of sand upcoast of the jetty.

Figures 10(a) and 10(b) respectively show the calculated and measured longitudinal profiles along transect Nos. 1-4, as shown in Fig. 7. The profile along transect No. 2, where sand was deposited, and the profiles along transect Nos. 3 and 4, where erosion occurred, were well reproduced in the calculation.

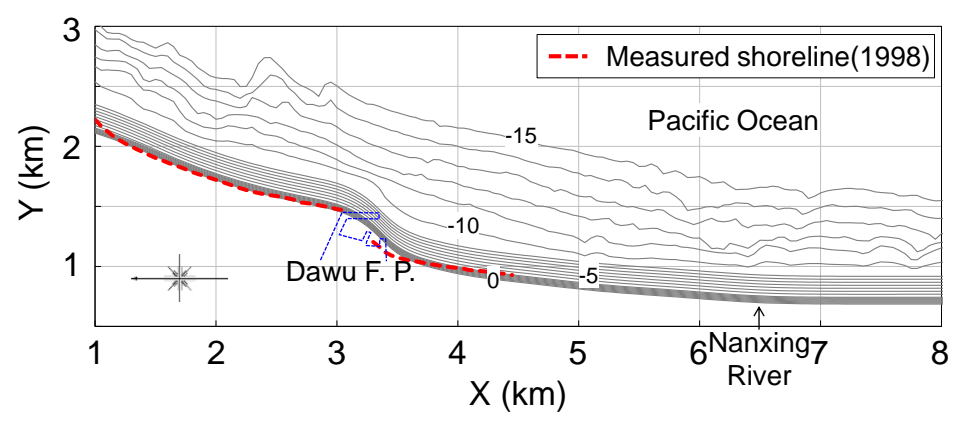

Figure 6. Reproduced bathymetry and measured shoreline in 1998.

(a) Calculated bathymetry

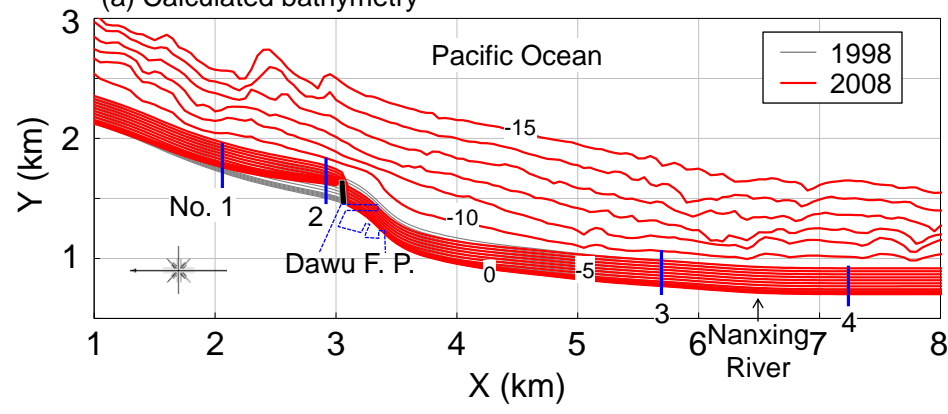

(b) Measured bathymetry

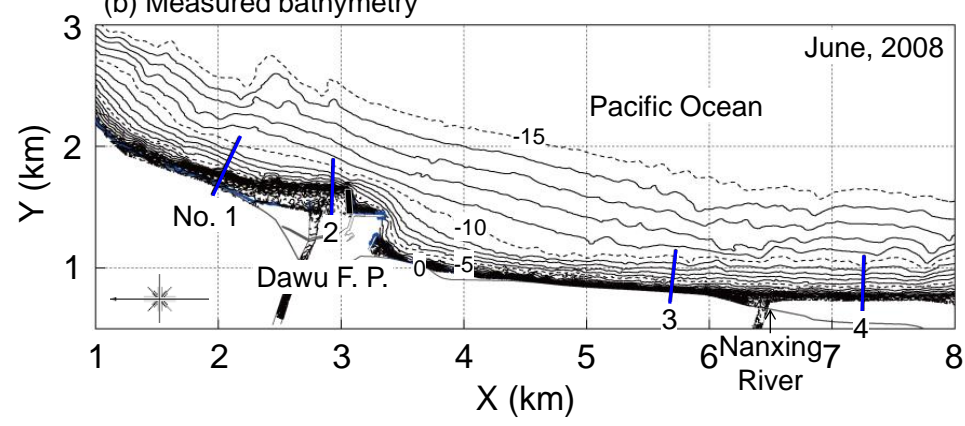

Figure 7. Measured and calculated bathymetries in 2008. 


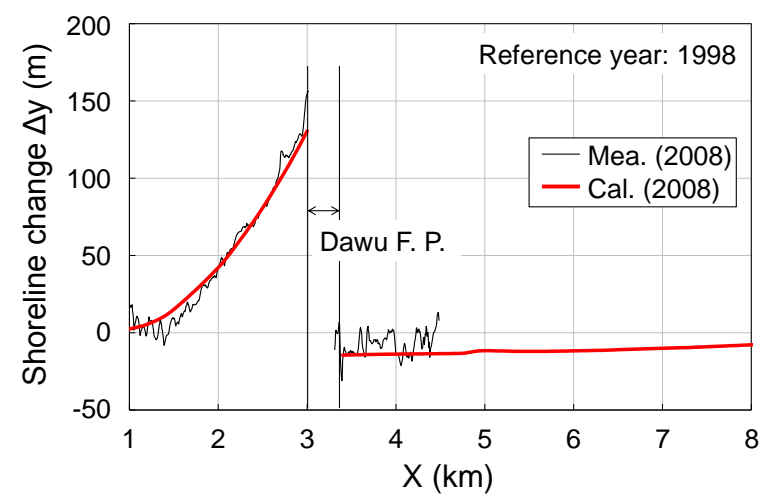

Figure 8. Measured and predicted shoreline changes between 1998 and 2008.

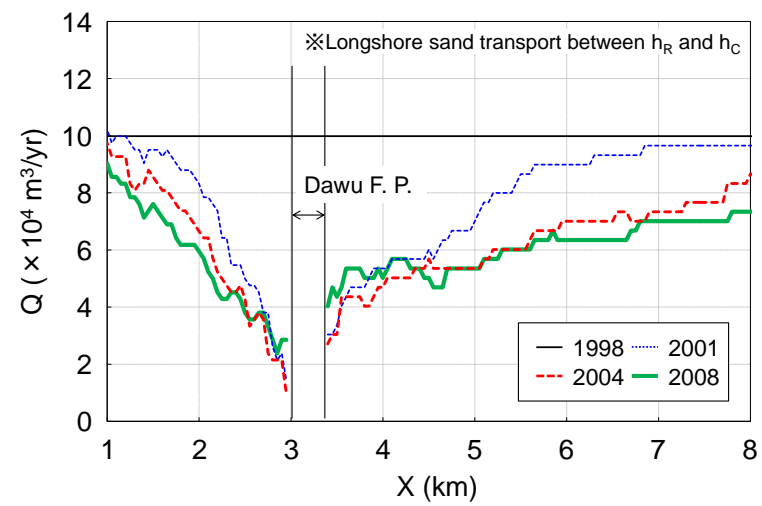

Figure 9. Distribution of longshore sand transport.

(a) Calculated

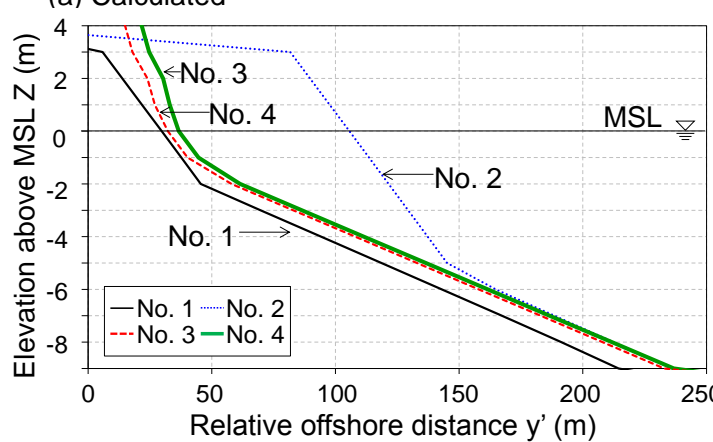

(b) Measured

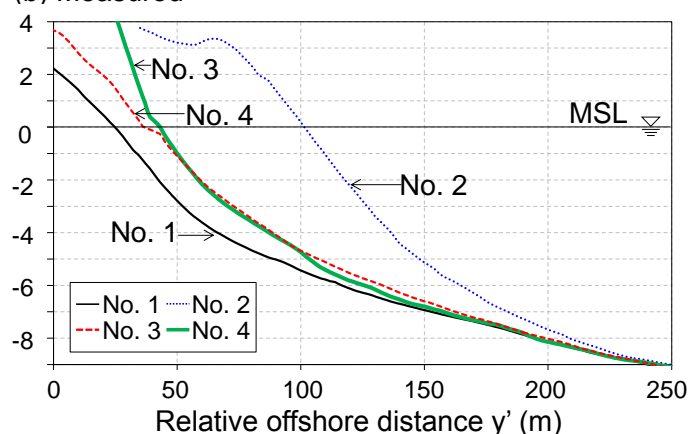

Figure 10. Measured and predicted longitudinal profiles superimposed along transect Nos. 1, 2, 3 and 4.

\section{RESULTS OF PREDICTION CALCULATION}

\section{Case 1 with no measures}

Beach changes until 2028 without any measures were predicted given the bathymetry in 2008 as the initial bathymetry. Figure 11 shows the predicted shoreline after 20 years. The upcoast shoreline gradually advanced, and thereafter, the shoreline advance in the vicinity of the jetty was reduced. Sand accumulation increased upcoast of the fishing port because of the continuous sand supply of $1.0 \times 10^{5} \mathrm{~m}^{3} / \mathrm{yr}$ from the upcoast, and the downcoast shoreline also advanced over time because part of the longshore sand transport turned around the tip of the jetty. 
The area where beach nourishment was adopted as a measure against beach erosion was the area with the beach width of less than $10 \mathrm{~m}$ (the area between $X=3.5$ and $X=4.8 \mathrm{~km}$ as shown in Fig. 12). The mean wave direction near the downcoast of the fishing port where measures are adopted is N94 $\mathrm{E}$, and this makes a $5^{\circ}$ counterclockwise wave incidence to the direction normal to the shoreline. To obtain a stable shoreline with a beach width of $10 \mathrm{~m}$ under the condition that sand supply from the upcoast is zero, the length and point depth must be 176 and $9 \mathrm{~m}$, respectively, at a location $1.3 \mathrm{~km}$ away from the first groin. However, such a long groin, the point depth of which reaches $9 \mathrm{~m}$, was considered to be difficult to construct and maintain.

A gentle slope of $1 / 30$ extends in the offshore zone deeper than $5 \mathrm{~m}$ as shown by the profiles along transect Nos. 3 and 4 in Fig. 10, although beach nourishment is to be carried out on the steep slope of $1 / 3$. If the point depth of the groin is assumed to be $5 \mathrm{~m}$, taking the stability of the groin into account, the maximum intervals between the groins must be $200 \mathrm{~m}$ to produce a stable beach with the minimum beach width of $10 \mathrm{~m}$. Therefore, beach changes were calculated in this study given the groin intervals of $200 \mathrm{~m}$.

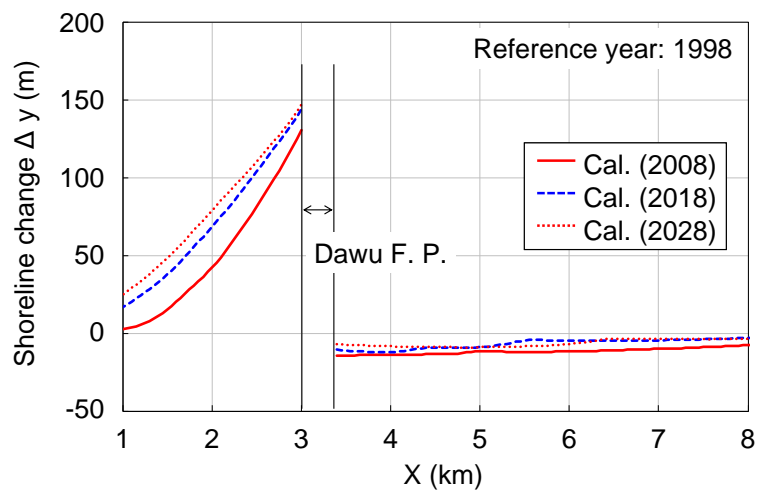

Figure 11. Predicted shoreline after 20 years.

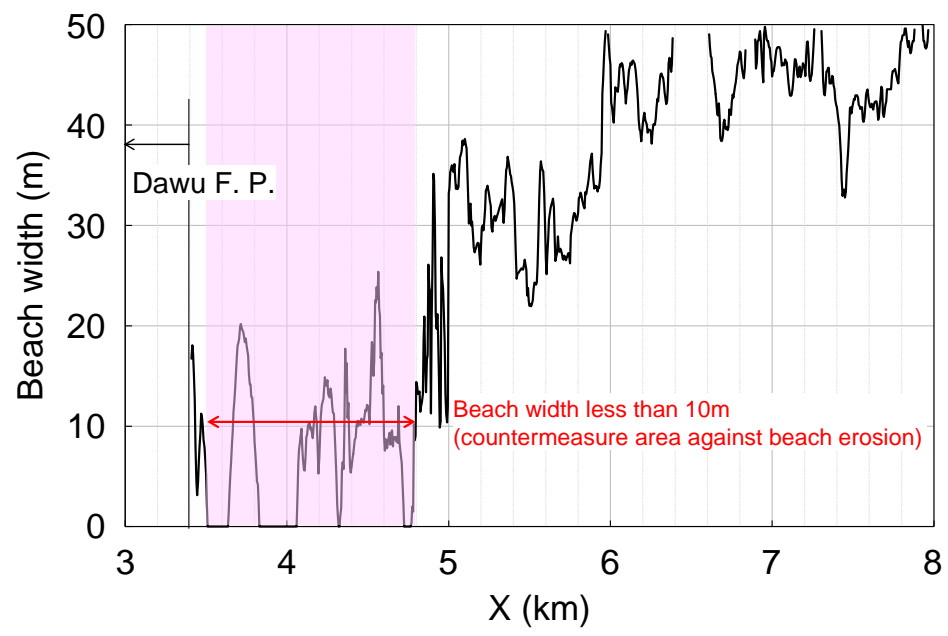

Figure 12. Longshore distribution of beach width.

\section{Case 2 (point depth of $5 \mathrm{~m}, 200 \mathrm{~m}$ intervals and beach nourishment of $5 \times 10^{4} \mathrm{~m}^{3}$ )}

Figures 13 and 14 respectively show the predicted bathymetry and shoreline changes with reference to that in 1998 in Case 2, where groins with a point depth of $5 \mathrm{~m}$ were installed at $200 \mathrm{~m}$ intervals and $5 \times 10^{4} \mathrm{~m}^{3}$ of gravel was nourished between the groins to obtain an initial beach width of $10 \mathrm{~m}$. The shoreline changes demonstrate that the shoreline immediately downcoast of the three groins located between $X=4.1$ and $4.8 \mathrm{~km}$ results in a beach width of less than $10 \mathrm{~m}$ until 2018, 
although the shoreline advanced with the beach width exceeding 10 m between $X=3.5$ and $4.1 \mathrm{~km}$. Then, part of the southward longshore sand transport turned around the entrance of the Dawu fishing port and was deposited downcoast, resulting in the shoreline advance and a beach width of over $10 \mathrm{~m}$ in the planned area by 2028. Thus, longshore sand transport turning around the tip of the fishing port plays a vital role in maintaining the downcoast shoreline.

Figure 15 shows the bathymetry around the groins. In the area immediately south of the Dawu fishing port, the interval between the contours shallower than $-6 \mathrm{~m}$ was narrowed, implying the formation of a steep slope. This is because the longshore sand transport turning around the fishing port breakwater was trapped by the groins. On the other hand, the contours in the zone deeper than -7 $\mathrm{m}$ meandered offshore of the tip of the groins because part of the littoral sand was transported downcoast while turning around the tip of the groins. Furthermore, beach erosion became more severe downcoast of the southermost groin because sand was trapped on the upcoast.

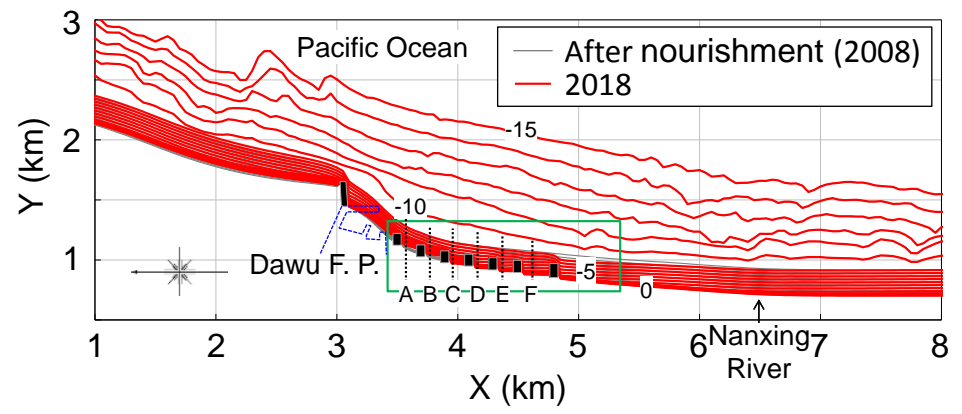

Figure 13. Predicted bathymetry in Case 2 (point depth of $5 \mathrm{~m}, 200 \mathrm{~m}$ intervals and beach nourishment of $5 \times$ $\left.10^{4} \mathrm{~m}^{3}\right)$.

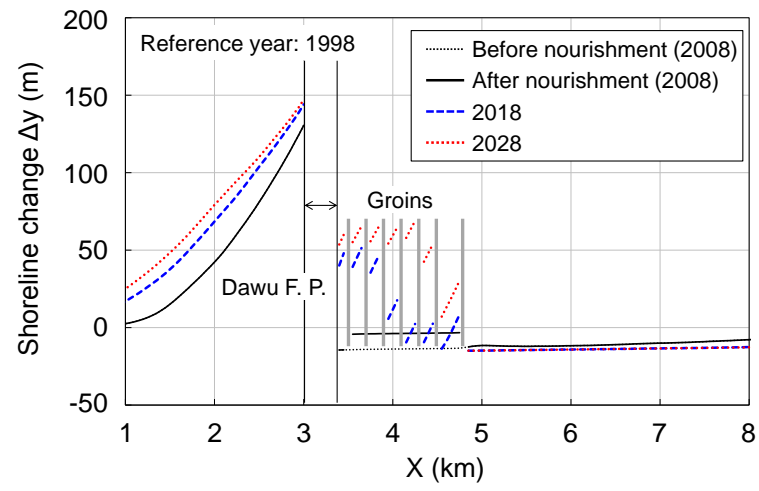

Figure 14. Shoreline changes with reference to that in 1998 (Case 2).

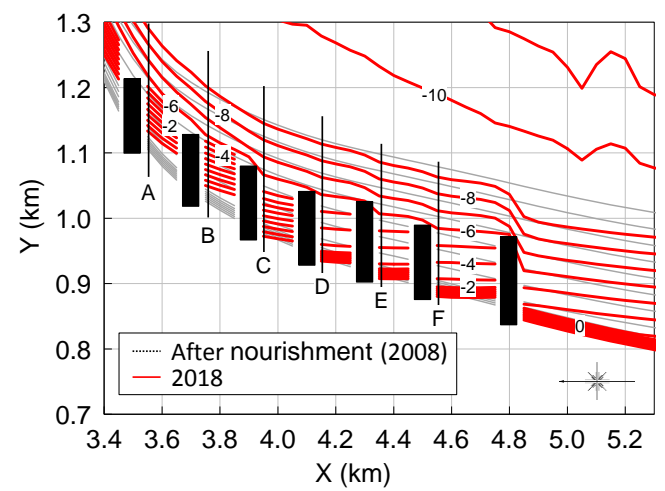

Figure 15. Detailed bathymetry around groins (Case 2). 


\section{Case 3 (Case $2+$ beach nourishment of $2.0 \times 10^{5} \mathrm{~m}^{3}$ )}

In Case 2, where beach nourishment using $5 \times 10^{4} \mathrm{~m}^{3}$ of gravel was carried out, and even in the case that the amount of beach nourishment was increased to $1.0 \times 10^{5} \mathrm{~m}^{3}$, the area where the beach width did not satisfy the minimum width of $10 \mathrm{~m}$ existed, and therefore, a numerical prediction was carried out with the amount of beach nourishment increased to $2.0 \times 10^{5} \mathrm{~m}^{3}$ while maintaining the same structural conditions of Case 2. Figures 16 and 17 show the predicted bathymetry and shoreline changes after 20 years with reference to that in 1998, respectively. The shoreline changes demonstrate that the beach has a minimum width of $10 \mathrm{~m}$ in the entire zone between groins.

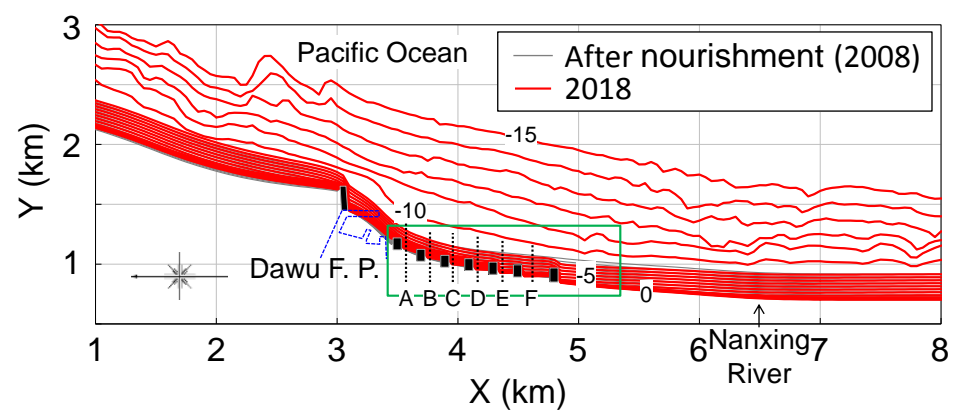

Figure 16. Predicted bathymetry in Case 3 (point depth of $5 \mathrm{~m}, 200 \mathrm{~m}$ intervals and beach nourishment of $2 \times 10^{5}$ $\mathbf{m}^{3}$ ).

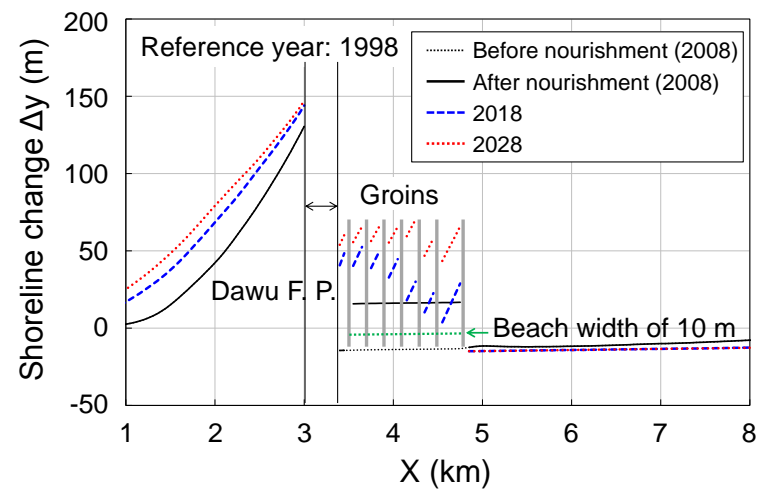

Figure 17. Shoreline changes with reference to that in 1998 (Case 3).

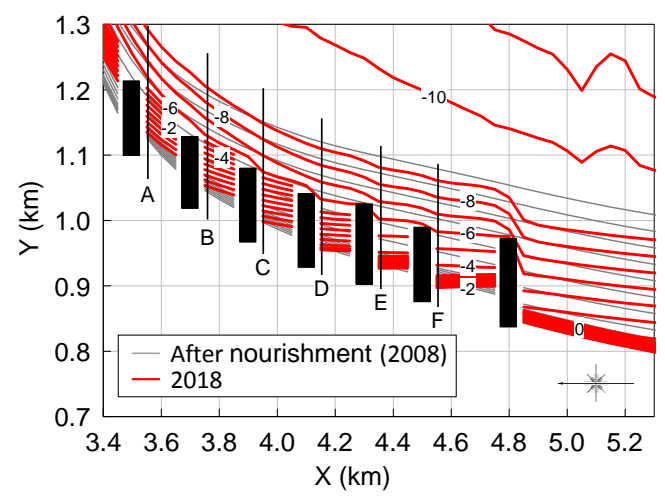

Figure 18. Detailed bathymetry around groins (Case 3). 
Figure 18 shows the detailed bathymetry around the groins. Between $X=3.5$ and $4.3 \mathrm{~km}$ (transects A-D), sand that turned around the fishing port was deposited, forming a seabed with a slope of $1 / 8$, whereas a stable beach was formed with a steep slope of $1 / 3$, owing to the beach nourishment using gravel, in the zone shallower than $-3 \mathrm{~m}$ between $X=4.3$ and $4.8 \mathrm{~km}$ (transects $\mathrm{E}$ and $\mathrm{F}$ ). However, in the offshore zone, the water depth gradually increases because of the lack of littoral sand.

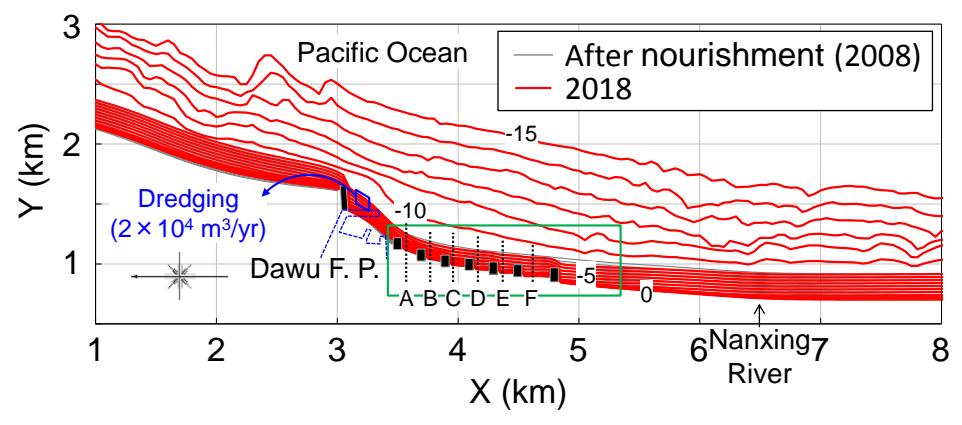

Figure 19. Predicted bathymetry in Case 4 (Case $3+$ sand mining of $2 \times 10^{4} \mathrm{~m}^{3} / \mathrm{yr}$ ).

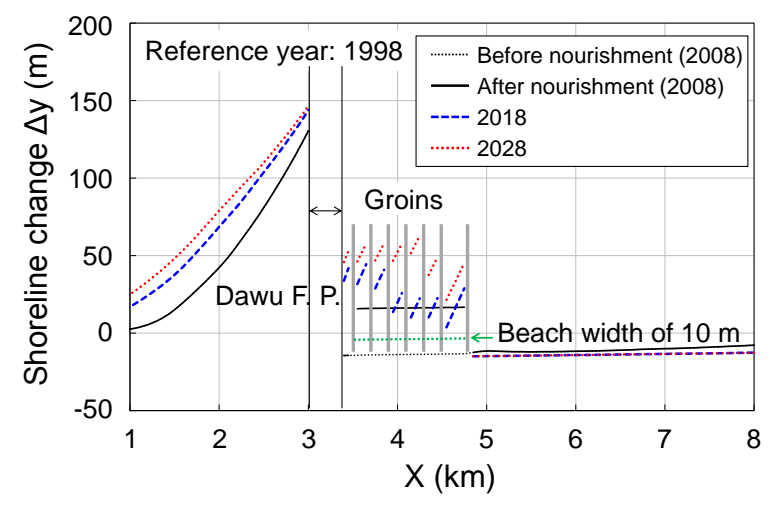

Figure 20. Shoreline changes with reference to that in 1998 (Case 4).

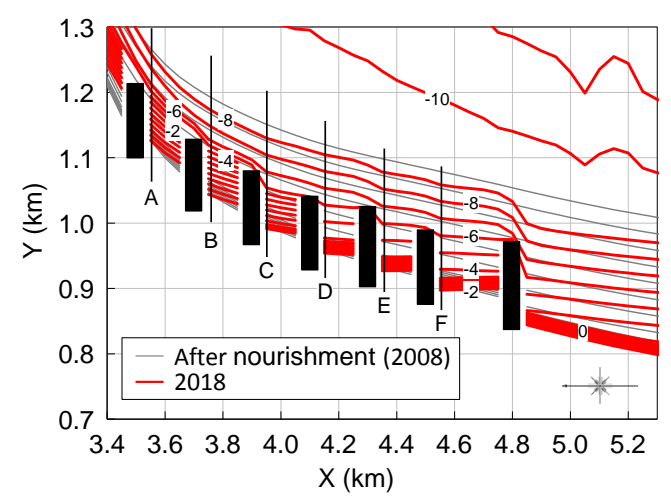

Figure 21. Detailed bathymetry around groins (Case 4).

\section{Case 4 (Case 3 + sand mining of $2.0 \times 10^{4} \mathrm{~m}^{3}$ )}

Sand mining has been carried out at the entrance of the Dawu fishing port. Although the amount of mined sand is unknown, a considerable amount of sand has been extracted from the shoreline. In this study, the amount of mined sand was assumed to be $20 \%$ of the longshore sand tran sport of $2 \times 10^{4}$ 
$\mathrm{m}^{3} / \mathrm{yr}$ and its effect was investigated. The other conditions are the same as those in Case 3 . Figures 19 and 20 show the predicted bathymetry and the shoreline changes with reference to that in 1998, respectively. The shoreline changes demonstrate that a beach width over $10 \mathrm{~m}$ is maintained even if sand mining is carried out at the entrance of the fishing port, although the shoreline advance in the planned area becomes smaller than that in Case 3 because of the decrease in sand supply from the upcoast. Figure 21 shows the detailed bathymetry around the groins. Compared with the results in Case 3 (Fig. 18), the sand deposition on the foreshore decreased along transects A, B and C in response to the decrease in sand supply from the upcoast.

\section{CONCLUSION}

On the basis of the field data taken around the Dawu fishing port, wave direction, berm height, depth of closure and longshore sand transport at the updrift end of the coast were determined to be $\mathrm{N} 91^{\circ} \mathrm{E}$ at a point $X=2.8 \mathrm{~km}$ upcoast of the fishing port, $h_{R}=3.5 \mathrm{~m}, h_{c}=-9 \mathrm{~m}$ and $1.03 \times 10^{5} \mathrm{~m}^{3} / \mathrm{yr}$, respectively; the assumed grain size for nourishment materials in this study was $d_{50}=60 \mathrm{~mm}$ (given an equilibrium slope of 1/3). Using these data sets, a dynamically equilibrium beach with constant longshore sand transport was reproduced along with the calculation of the wave field. Moreover, the minimum width of the beach was assumed to be $10 \mathrm{~m}$. The area between $X=3.5$ and $4.8 \mathrm{~km}$ was determined to be the area where beach nourishment is required. In this area, if seven groins with 200 $\mathrm{m}$ intervals are constructed and beach nourishment using $2.0 \times 10^{5} \mathrm{~m}^{3}$ of gravel (grain size of $60 \mathrm{~mm}$ and equilibrium slope of 1/3) is carried out, then the beach width can be widened to over $10 \mathrm{~m}$. Furthermore, numerical simulation in the case of sand mining of $2 \times 10^{4} \mathrm{~m}^{3} / \mathrm{yr}$ at the entrance of the Dawu fishing port was also carried out. Even if sand mining is carried out, a beach width greater than the minimum planned width of $10 \mathrm{~m}$ can be accomplished by gravel nourishment. However, even in this case, beach erosion becomes severe over time on the downcoast and the decrease in offshore seabed elevation cannot be avoided. Sand supply to the downcoast of the planned area will decrease because of the installation of groins, and future downcoast beach erosion is a concern. Although the extension of the upcoast jetty is a way of gaining time to solve this problem, it is inevitable that downcoast erosion will reoccur. It is concluded that all measures, except sand bypassing from the entrance channel to the downcoast, are required in the long term.

\section{REFERENCES}

Ashton, A., A. B. Murray, and O. Arnault. 2001. Formation of coastline features by large-scale instabilities induced by high angle waves, Nature, Vol. 414, pp. 296-300.

Dally, W. R., R. D. Dean, and R. A. Dalrymple. 1984. A model for breaker decay on beaches, Proc. 19th ICCE, pp. 82-97.

Kamphius, J. W., M. H. Davies, R. B. Narim, and O. J. Sayao. 1986. Calculation of littoral sand transport rate, Coastal Eng., Vol. 10, pp. 1-12.

Kraus, N. C. 1985. Field experiments on vertical mixing of sand in the surf zone, J. Sedimentary Petrology, Vol. 55, pp. 3-14.

Kumada, T., A. Kobayashi, T. Uda, and M. Serizawa. 2003. Development of predictive model of shoreline and grain size changes, Proc. 5th Int. Symp. on Coastal Eng. and Science of Coastal Sediment Processes, ASCE, pp. 1-14.

Mase, H. 2001. Multidirectional random wave transformation model based on energy balance equation, Coastal Eng. J., JSCE, Vol. 43, No. 4, pp. 317-337.

Ozasa, H., and A. H. Brampton. 1980. Model for predicting the shoreline evolution of beaches backed by seawalls, Coastal Eng., Vol. 4, pp. 47-64.

So, S. 1970. Sand transport around Dawu fishing port on east coast of Taiwan, Ann. J. Coastal Eng., JSCE, Vol. 17, pp. 275-282. (in Japanese)

Uda, T., and S. Kawano. 1996. Development of a predictive model of contour line change due to wave, Proc. JSCE, No.539/ II -35, pp. 121-139. (in Japanese)

Uda, T., T. Kumada, and M. Serizawa. 2004. Predictive model of change in longitudinal profile in beach nourishment using sand of mixed grain size, Proc. 29th ICCE, ASCE, pp. 3378-3390.

Uda, T., and M. Serizawa. 2010. Model for predicting topographic changes on coast composed of sand of mixed grain size and its applications, pp. 327-358, in 'Numerical simulations-examples and applications in computational fluid dynamics', Angermann, L. ed., INTEC. 